\title{
Penerapan Metode Tutor Sebaya untuk Meningkatkan Hasil Belajar Siswa pada Materi Rumus dan Fungsi Microsoft Excel
}

\author{
Hari Widiayanto \\ SMP Negeri 6 Kebumen \\ ankebhoe@gmail.com
}

\section{Sejarah Artikel}

diterima 13/12/2019

diterbitkan 31/12/2019

\begin{abstract}
The purpose of this study is to improve student learning outcomes in the material formula and functions of Microsoft Excel. This research is a classroom action research $(C A R)$ carried out in two cycles, each cycle consisting of planning, implementing, observing, and reflecting. The subjects of this study were students of class VII $F$ of SMP Negeri 6 Kebumen in the academic year 2019/2020, amounting to 32 students. Data collection techniques using observation and tests. Data analysis includes data reduction, data presentation, and drawing conclusions. Research shows that the application of Peer Tutor learning methods can improve student learning outcomes in formula and function material in Microsoft Excel in class VII F of SMP Negeri 6 Kebumen in the academic year 2019/2020 as evidenced by the percentage of completeness of learning outcomes in the first cycle by $68.5 \%$ to $94 \%$ in cycle II.
\end{abstract}

Keywords: Peer Tutor, Microsoft Excel, Student

\section{Abstrak}

Tujuan penelitian ini adalah meningkatkan hasil belajar siswa pada materi mengenal rumus dan fungsi microsoft excel. Penelitian ini merupakan penelitian tindakan kelas (PTK) yang dilaksanakan dalam dua siklus, setiap siklus terdiri dari tahap perencanaan, pelaksanaan, observasi, dan refleksi. Subjek penelitian ini adalah peserta didik kelas VII F SMP Negeri 6 Kebumen tahun pelajaran 2019/2020 yang berjumlah 32 peserta didik. Teknik pengumpulan data menggunakan observasi dan tes. Analisis data meliputi reduksi data, penyajian data, dan penarikan kesimpulan. Penelitian menunjukkan bahwa penerapan metode pembelajaran Tutor Sebaya dapat meningkatkan hasil belajar siswa pada materi mengenal rumus dan fungsi pada microsoft excel di kelas VII F SMP Negeri 6 Kebumen tahun pelajaran 2019/2020 yang dibuktikan dengan persentase ketuntasan hasil belajar pada siklus I sebesar $68.5 \%$ menjadi $94 \%$ pada siklus II.

Kata kunci: Tutor Sebaya, Microsoft Excel, Siswa 


\section{PENDAHULUAN}

Informatika merupakan salah satu disiplin ilmu yang berfungsi untuk mengembangkan kemampuan berpikir manusia dalam mengatasi persoalan yang semakin kompleks. Untuk menghadapi tantangan zaman tersebut, langkah strategis ditempuh Kemdikbud dengan menetapkan Permendikbud No. 35-37 tahun 2018 yang menambahkan dan mengintegrasikan muatan informatika pada kompetensi dasar dalam kerangka dasar dan struktur kurikulum 2013 pada jenjang SMP dan SMA (https://www.usd.ac.id). Informatika dipelajarai di jenjangpendidikan SMP dan SMA, sedangkan di jenjang pendidikanSekolahDasar (SD), Informatika dapat menjadi materi kokurikuler atau ekstrakurikuler.

Muatan/mapel Informatika berisi seperangkat $\mathrm{KI}$ (kompetensi inti) dan KD (kompetensi dasar) yang dirancang untuk memberikan "bekal" keilmuan informatika kepada peserta didik jenjang pendidikan dasar dan menengah. Bekal tersebut meliputi: berpikir, berkarya dan terampil, berpengetahuan dan berkarakter (Balitbang Kemdikbud, 2019).

Salah satu materi Informatika adalah aplikasi pengolah angka Microsoft excel. Microsoft Excel merupakan salah satu perangkat lunak pengolah angka yang paling sering digunakan. Masalah-masalah perhitungan dapat diselesaikan melalui aplikasi perangkat lunak tersebut. Ada beberapa perangkat lunak pengolah angka yang dikenal diantaranya, Kspread, Star Office Calc, Open Office Calc, Lotus 123, dan Microsoft Excel (Setiana, 2019).

Untuk mencapai tujuan tersebut, ternyata ditemui beberapa kendala seperti: (1) Kurangnya motivasi siswa dalam mengikuti kegiatan pembelajaran; (2) Siswa merasa kesulitan mempelajari Microsoft Excel terutama pada materi rumus dan fungsi; (3) Siswa kurang terlatih dan terampil mengaplikasikan rumus dan fungsi pada Microsoft Exceluntuk memecahkan masalah dalam kehidupan sehari hari. Hal tersebut diperkuat dengan hasil belajar pada penilaian harian siswa menunjukkan 12 orang siswa mencapai KKM, dan sisanya belum mencapai KKM.

Kendala-kendala yang muncul tersebut, diduga karena: (1) Pembelajaran yang dilaksanakan masih bersifat konvensional; (2) Guru merasa kesulitan menemukan model pembelajaran yang tepat untuk menjelaskan Microsoft Excel;(3) Tidak ada variasi media untuk menyampaikan materi pelajaran, hanya menggunakan LCD Proyektor. Untuk mengatasi kendala tersebut, maka penulis mecoba melakukan perbaikan pembelajaran menggunakan metode tutor sebaya. Metode tutor sebaya dikenal dengan pembelajaran teman sebaya atau pemberian pembelajaran antar siswa atau peserta didik (Safrudin, 2014). Peserta didik yang lebih mampu menyelesaikan pekerjaannya sendiri, dan kemudian membantu peserta didik lain yang kurang mampu (Arjanggi, 2010). Hal ini merupakan strategi untuk mendukung pengajaran, sesama peserta didik didalam kelas. Metode tutor sebaya terbuktidapat meningkatkan hasil belajar siswa materi Microsoft Excel (Siregar, 2016).

Berdasarkan uraian diatas, penulisakan mencoba melakukan penelitian dengan judul Penerapan Metode Tutor Sebaya Untuk Meningkatkan Hasil Belajar Siswa 
Pada Materi Mengenal Rumus dan Fungsi Microsoft Excel di Kelas VII F SMP Negeri 6 Kebumen Tahun Pelajaran 2019/2020. Tujuan penelitian ini adalah meningkatkan hasil belajar siswa pada materi mengenal rumus dan fungsi microsoft excel.

\section{METODE}

Penelitian ini merupakan penelitian tindakan kelas (PTK) kolaboratif yang dilaksanakan dalam dua siklus, setiap siklus terdiri dari tahap perencanaan, pelaksanaan, observasi, dan refleksi. Subjek penelitian ini adalah peserta didik kelas VII F SMP Negeri 6 Kebumen tahun pelajaran 2019/2020 yang berjumlah 32 peserta didik.
Data yang dianalisis berupa data kualitatif yaitu penggunaan metode tutor sebaya dan data kuantitatif yaitu hasil belajar Informatika peserta didik. Teknik pengumpulan data menggunakan observasi dan tes. Uji validitas data menggunakan triangulasi teknik dan triangulasi sumber. Analisis data meliputi reduksi data, penyajian data, dan penarikan kesimpulan.

\section{PEMBAHASAN}

Berdasarkan analisis hasil penelitian yang telah diuraikan maka pembahasan pada penelitian ini sebagai berikut.

\section{Penerapan Metode Tutor Sebaya}

Hasil penelitian menunjukkan peningkatan penerapan metode tutor sebaya yang dilakukan oleh guru. Terilha pada tabel berikut.

Tabel 1. Peningkatan Penerapan Metode Tutor Sebaya

\begin{tabular}{lccccc}
\hline \multicolumn{1}{c}{ Langkah } & \multicolumn{2}{c}{ Siklus I } & \multicolumn{2}{c}{ Siklus II } \\
\cline { 2 - 6 } & Pert. 1 & Pert. 2 & Pert. 1 & Pert. 2 \\
\hline $\begin{array}{l}\text { Menyusun kelompok belajar dan memilih } \\
\text { tutor sesuai jumlah kelompok }\end{array}$ & 2 & 3 & 4 & 4 \\
\hline $\begin{array}{l}\text { Menjelaskan peran tutor dan melatih tutor } \\
\text { terkait materi yang akan dipelajari }\end{array}$ & 2 & 3 & 3 & 3 \\
\hline $\begin{array}{l}\text { Menjelaskan materi pelajaran secara ringkas } \\
\text { pada semua peserta didik }\end{array}$ & 4 & 4 & 4 & 4 \\
\hline $\begin{array}{l}\text { Memberi tugas kepada semua peserta didik } \\
\text { dan mengarahkan tutor untuk membantu } \\
\text { peserta didik lain }\end{array}$ & 3 & 3 & 3 & 4 \\
\hline $\begin{array}{l}\text { Mengamati aktivitas belajar dan member } \\
\text { penilaian kompetensi }\end{array}$ & 3 & 3 & 3 & 3 \\
\hline Melakukan evaluasi pembelajaran & 4 & 4 & 4 & 4 \\
\hline $\begin{array}{l}\text { Rata-rata } \\
\text { Prosentase ketuntasan }\end{array}$ & $\mathbf{3 . 0}$ & $\mathbf{3 . 3}$ & $\mathbf{3 . 5}$ & $\mathbf{3 . 7}$ \\
\hline
\end{tabular}


Penerapan Metode Tutor Sebaya dalam pembelajaran Informatika meliputi langkah-langkah: (1) Guru menyusun kelompok belajar. Setiap kelompok beranggotakan 3 atau 4 orang yang memiliki kemampuan beragam. Guru mengidentifikasi beberapa peserta didik yang memiliki kemampuan yang lebih baik daripada temannya di kelas yang sama untuk dijadikan tutor. Jumlah tutor sama dengan jumlah kelompok belajar yang akan dibentuk; (2) Guru menjelaskan wewenang, tanggung jawab tutor, latihan serta valuasi yang akan dilakukan dan melatih tutor dalam materi yang akan dipelajari oleh kelas; (3) Guru menjelaskan materi pelajaran secara ringkas pada semua peserta didik dan memberikan kesempatan tanya jawab; (4) Guru memberi tugas, dengan catatan peserta didik yang kesulitan dalam mengerjakan tugas dapat meminta bimbingan kepada teman yang ditunjuk sebagai tutor oleh guru dan memberikan penjelasan materi yang belum dipahami oleh temannya dalam satu kelompok; (5) Guru mengamati aktivitas belajar dan memberi penilaian kompetensi. (6) Guru, tutor, dan peserta didik memberikan evaluasi proses belajar mengajar untuk menetapkan tindak lanjut.

Langkah-langkah metode Tutor Sebaya dilaksanakan dalam penelitian ini sejalan dengan penelitian yang dilakukan oleh Hastuti (2018) yang melakukan penelitian dengan topik Penerapan Metode Pembelajaran Tutor Sebaya Untuk Meningkatkan Keaktifan Dan Hasil Belajar Siswa Pada Mata Pelajaran Desain Grafis Kelas X Multimedia 1 Di SMK N 1 Godean.

\section{Hasil Belajar pada materi rumus dan fungsi Microsoft excel}

Hasil penelitian menunjukkan peningkatan hasil belajar pada materi rumus dan fungsi microsoft excel. Terilaht pada tabel berikut.

Tabel 2. Peningkatan Hasil Belajar

\begin{tabular}{ccccccccc}
\hline \multirow{2}{*}{ Nilai } & \multicolumn{4}{c}{ Siklus I } & \multicolumn{5}{c}{ Siklus 2 } \\
\cline { 2 - 11 } & \multicolumn{2}{c}{ Pert. 1 } & \multicolumn{2}{c}{ Pert. 2 } & \multicolumn{2}{c}{ Pert. 1 } & \multicolumn{2}{c}{ Pert. 2 } \\
\cline { 2 - 10 } & $\mathbf{f}$ & $\%$ & $\mathbf{f}$ & $\%$ & $\mathbf{f}$ & $\%$ & $\mathbf{f}$ & $\%$ \\
\hline 100 & 2 & 6.3 & 8 & 25.0 & 11 & 34.4 & 3 & 9.4 \\
\hline 90 & 5 & 15.6 & 6 & 18.8 & 12 & 37.5 & 7 & 21.9 \\
\hline 80 & 11 & 34.4 & 14 & 43.8 & 9 & 28.1 & 16 & 50.0 \\
\hline 70 & 4 & 12.5 & 1 & 3.1 & 0 & 0 & 2 & 6.3 \\
\hline 60 & 5 & 15.6 & 3 & 9.4 & 0 & 0 & 3 & 9.4 \\
\hline 50 & 3 & 9.4 & 0 & 0 & 0 & 0 & 1 & 3.1 \\
\hline 40 & 2 & 6.3 & 0 & 0 & 0 & 0 & 0 & 0 \\
\hline Jumlah & 32 & 100 & 32 & 100 & 21 & 100 & 32 & 100 \\
\hline Rata-rata & $\mathbf{7 3 . 1 3}$ & - & $\mathbf{8 4 . 6 9}$ & - & $\mathbf{9 0 . 6 3}$ & - & $\mathbf{8 0 . 6 3}$ & - \\
\hline Tuntas & $\mathbf{1 8}$ & $\mathbf{5 6}$ & $\mathbf{2 8}$ & $\mathbf{8 8}$ & $\mathbf{3 2}$ & $\mathbf{1 0 0}$ & $\mathbf{2 6}$ & $\mathbf{8 1}$ \\
\hline
\end{tabular}

Peningkatan hasil belajar Informatika peserta didik pada materi mengenal rumus dan fungsi Microsoft excel diukur dengan menggunakan teknik tes hasil belajar dengan instrument lembar soal evaluasi. Teknik pengumpulan data hasil belajar peserta didik diterapkan disetiap 
pertemuan setelah dilakukan proses pembelajaran. Aspek yang diukur yaitu aspek kognitif atau pengetahuan yang terdiri dari mengingat (C1), memahami (C2), mengaplikasi (C3), dan menganalisis (C4) yang diukur berdasarkan hasil evaluasi setelah mengikuti pembelajaran dengan penggunaan metode Tutor Sebaya pada materi mengenal rumus dan fungsi Microsoft excel.

Penggunaan metode Tutor Sebaya dalam pembelajaran Informatika dapat meningkatkan hasil belajar peserta didik di kelas VII F SMP Negeri 6 Kebumen secara signifikan. Pada hasil Penilaian sebelumnya terdapat 12 dari 32 peserta didik yang belum mencapai KKM dengan persentase ketuntasan hasil belajar hanya $37.5 \%$. Setelah dilakukan tindakan, persentase ketuntasan hasil belajar pada siklus I meningkat menjadi $56 \%$ dan pada pertemuan kedua menjadi $81 \%$. Pada siklus II terjadi peningkatan kembali pada pertemuan pertamamenjadi $88 \%$ dan pertemuan kedua mencapai $100 \%$. Berdasarkan hasil di atas, ratarata ketuntasan hasil belajar pada siklus I sebesar $68.50 \%$ dan siklus II sebesar $94 \%$. Pada siklus I pertemuan pertama belum mencapai indikator kinerja penelitian yang ditetapkan. Hasil belajar pada siklus I pertemuan kedua telah mencapai indikator kinerja penelitian dan terus meningkat pada siklus II. Pada siklus II pertemuan kedua, ketuntasan hasil belajar Informatika peserta didik telah mencapai $100 \%$ dengan KKM 75 sehingga pelaksanaan tindakan dapat dihentikan.

Berdasarkan analisis hasil belajar peserta didik setelah pelaksanaan tindakan, dapat diambil kesimpulan bahwa penggunaan metode Tutor Sebaya dapat meningkatkan hasil belajar Informatika pada materi mengenal rumus dan fungsi Microsoft excel. Hal ini sesuai dengan hasil penelitian yang dilakukan oleh Hari Indrawan Siregaryang membuktikan bahwa metode Tutor Sebaya dapat meningkatkan hasil belajar Informatika di kelas VII SMP secara signifikan. Hasil penelitian ini juga memperkuat pendapat Mujoyana (2015) Bahwa penggunaan metode Tutor Sebaya berpengaruh baik pada proses pembelajaran dan hasil belajar Informatika meningkat secara signifikan.

\section{SIMPULAN}

Berdasarkan hasil penelitian dan uraian pembahasan maka dapat diambil simpulan sebagai berikut.

Penggunaan metode Tutor Sebaya untuk meningkatkan hasil belajar Informatika pada materi mengenal rumus dan fungsi Microsoft exceldi kelas VII F SMP Negeri 6 Kebumen Tahun Pelajaran 2019/2020 dilaksanakan dengan langkah-langkah (1) Menyusun kelompok belajar dan memilih tutor sesuai jumlah kelompok, (2) Menjelaskan peran tutor dan melatih tutor terkait materi yang akan dipelajari, (3) Menjelaskan materi pelajaran secara ringkas pada semua peserta didik, (4) Memberi tugas kepada semua peserta didik dan mengarahkan tutor untuk membantu peserta didik lain, (5) Mengamati aktivitas belajar dan memberi penilaian kompetensi, dan (6) Melakukan evaluasi pembelajaran. 
Penggunaan metode Tutor Kebumen tahun pelajaran 2019/2020 Sebaya dapat meningkatkan hasil yang dibuktikan dengan rata-rata belajar Informatika pada materi ketuntasan hasil belajar peserta didik mengenal rumus dan fungsi Microsoft pada siklus I sebesar $68.5 \%$ dan Excel di kelas VII F SMP Negeri 6 meningkat menjadi 94\% pada siklus II.

\section{DAFTAR PUSTAKA}

Arjanggi, R., \& Suprihatin, T. (2010). Metode pembelajaran tutor teman sebaya meningkatkan hasil belajar berdasar regulasidiri. Hubs-Asia, 10 (1).

Balitbang Kemdikbud. (2019). Pedoman Implementasi Muatan/Mata Pelajaran Informatika Kurikulum 2013. Jakarta: Balitbang Kemdikbud.

Hastuti, D. N. (2018). Penerapan Metode Pembelajaran Tutor Sebaya untuk Meningkatkan Keaktifan dan Hasil Belajar Siswa Pada Mata Pelajaran Desain Grafis Kelas $X$ Multimedia 1 di SMKN 1 Godean. Skripsi pada Universitas Negeri Yogyakarta. Yogyakarta: UNY.

Mujoyana, M. (2015). Penerapan model pembelajaran tutor sebaya berbantuan Power Point untuk meningkatkan hasil belajar materi himpunan kelas VII MTs Baitussalam Semarang (Doctoral dissertation, UIN Walisongo).

Sanjaya, W. (2009) Penelitian Tindakan Kelas. Jakarta: Kencana.

Setiana, E. ( 2019). Informatika untuk SMP/MTs Kelas VII. Bandung: Grafindo.

Siregar, H. I. (2016). Pengelolaan Metode Tutor Sebaya dalam Meningkatkan Motivasi Belajar Siswa pada Pembelajaran Microsoft Excel di Kelas VIII-D Smp Negeri 1 Batangkuis. Jurnal Handayani PGSD FIP UNIMED, 6(1). 